\title{
Analysis of Domestic Cargo Service of Juanda Airport in Surabaya
}

\author{
Raditya Bromantiyo Bayu A. \\ Narotama University, Surabaya \\ Rbromantyo98@gmail.com
}

\begin{abstract}
Fulfillment freight user expectations of service quality is important for service organizations to face business competition. This analysis aims to determine what factors affect the service in the cargo terminal, create a model of the relationship between the factors that affect performance cargo terminal services, provides recommendation to improve the performance of services Cargo Terminal at Juanda Airport in Surabaya. The method used in this analysis is the Importance Performance Analysis (IPA) and the Customer Satisfaction Index (CSI). Respondents came from the expedition Air Freight and of the cargo transport services. IPA analysis known level of service performance still needs to be improved is the creation in serving customers queuing system, compensation for lost property damage in full, Leisure area of customer service, and the availability of parking facilities luas.Hasil CSI analysis resulting interpretation in value by $71.35 \%$. This means that customers are quite satisfied primarily domestic cargo terminal services Juanda Airport in Surabaya.
\end{abstract}

Keywords: Level of Service Performance, Domestic Cargo, IPA, CSI.

\section{INTRODUCTION}

Juanda Airport is a hub for domestic airport, pioneer and foreign countries in western Indonesia. Cargo transport at airports juanda every year to experience growth. In this case, the growth of cargo at airport Juanda require attention to the quality of service from time to time becomes very important. In the service industry, the quality of service to customers is the most important factor, because the customer is increasingly critical in selecting services to be used. (Sudarno et al, 2006).

To maximize customer service, air transportation also need a good supporting facilities to meet the needs and mobility of customers who will use the services of air cargo. One of the most important facilities for air cargo services that improve the cargo terminal. Based on the above problems can be formulated as follows:

1. Is the Cargo terminal services at Juanda Airport is optimal?

2. The type of service what needs to be prioritized from the service provider to be improved?

The purpose of this research to:

1. Obtaining the optimization level of service at the Domestic Airport Cargo Terminal Juanda

2. Getting the kind of services that need to be addressed and improved in the Domestic Cargo Terminal Juanda In doing research at Juanda Airport Cargo betasan defined as follows:

1. The data is used to perform an analysis of survey data obtained in PT. Angkasa Pura Cargo

2. Analysis of freight services performed at Juanda Airport cargo terminal.

3. Conducting a survey of service according to customer expectations Cargo Juanda Airport.

Analysis of Domestic Cargo Service of Juanda Airport in Surabaya

Raditya Bromantiyo Bayu A 


\subsection{Services}

\section{REVIEW OF LITERATURE}

According to Parasuraman et.al. (1988) found five (5) basic dimensions of service are:

1. Direct evidence (tangible), including physical facilities, supplies or equipment and performance of employees,

2. Reliability (reliability), namely the ability to provide the promised service with immediate, accurate and satisfying,

3. Responsiveness (responsiveness), namely the desire unruk help customers and provide service with responsiveness,

4. Guarantee (assurance), including knowledge, skills, courtesy and trustworthiness owned by its employees, free from danger, risk or doubt,

5. Empathy (empathy), covering care or attention, simplicity in relationships, good communication and understanding the needs of its customers.

\subsection{Quality}

Yuliana (2017) states that traditionally quality can be viewed as conformity to specifications. Quality can be applied to the manufacturing company and its products. Quality means it can meet or exceed customer expectations.

\section{METHODOLOGY}

Picture 1. Flowchart of the research phase

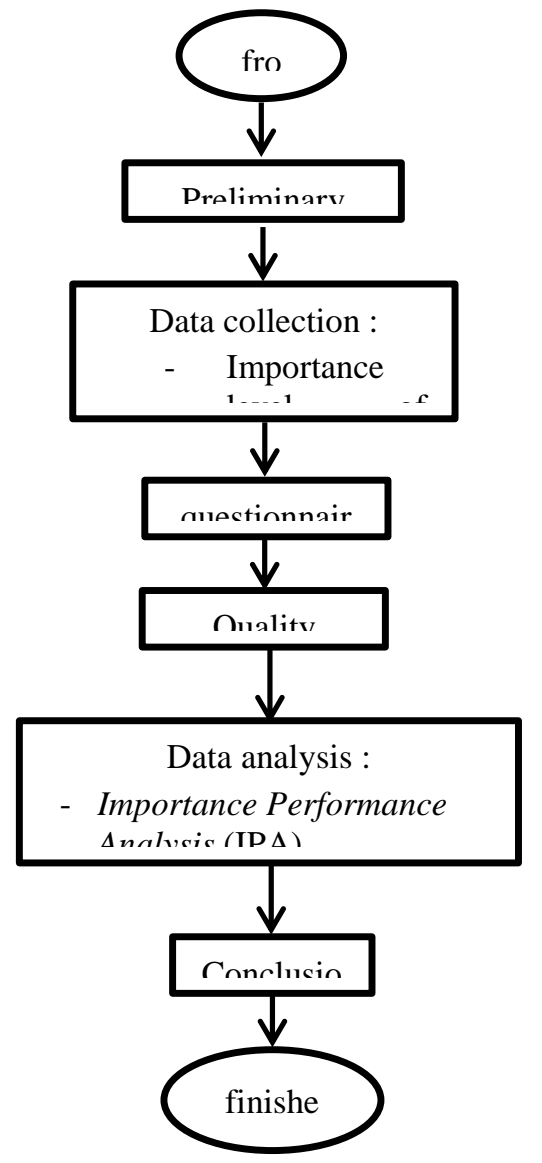

Analysis of Domestic Cargo Service of Juanda Airport in Surabaya

Raditya Bromantiyo Bayu A 


\subsection{Data collection}

The data used in this study a questionnaire data. The research data was obtained through a questionnaire to respondents about 20 (Twenty) service quality attributes with answer choices Likert scale of 5 (five). Respondents were asked to answer about satisfaction with care at every stage in the domestic cargo terminal. In this study the wear variable service quality dimensions, namely: Reliability, Responsiveness, Assurance, Empathy, and Physical Evidence.

Stages of research in the final project will be explained on flowcharts shown on Picture 1.

\subsection{Data analysis method}

\subsubsection{Importance Performance Analysis (IPA)}

In science there are several quadrants in order to obtain information which the performance level of service is low while the level of interest in these services is high, the level of service performance and the level of interest in these services is equally high level of service performance and the level of interest in these services are equally low, and high levels of service performance, but the level of interest to these services low

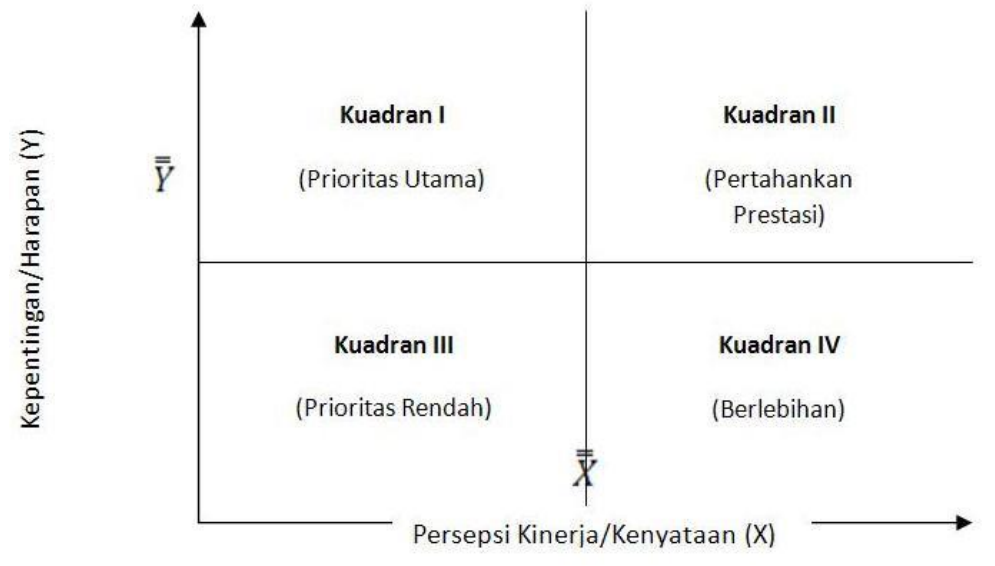

\subsubsection{Customer Satisfaction Index (CSI)}

Picture 2 Quadrant IPA

Customer Satisfaction Index (CSI) is a type of measurement used to determine the overall level of customer satisfaction with an approach that considers the level of expectation of the factors being measured. (Nurrasjid, 2013) As for the stages to measure Customer Satisfaction Index as follows:

1. Weighting Factors calculate by dividing the value of the average importance score that is obtained from each factor by the number of overall importance score.

2. Factors weighting value is multiplied by the value of satisfaction (statisfaction score) to obtain Weighted Score.

3. Weighted Score for each factor are summed so that the result is called Weighted Average.

4. Weighted Average divided Likert scale used later obtained value multiplied by $100 \%$ Satisfaction Index

Table 1 Interpretation of Results Calculation CSI

\begin{tabular}{|c|c|}
\hline Figures Index & Interpretation \\
\hline $\mathrm{X} \leq 64 \%$ & Very poor \\
\hline $64<\mathrm{X} \leq 71 \%$ & Poor \\
\hline $71<\mathrm{X} \leq 77 \%$ & Cause Of Concern \\
\hline $77<\mathrm{X} \leq 80 \%$ & Border line \\
\hline $80<\mathrm{X} \leq 84 \%$ & Good \\
\hline $84<\mathrm{X} \leq 87 \%$ & Very Good \\
\hline
\end{tabular}

Analysis of Domestic Cargo Service of Juanda Airport in Surabaya

Raditya Bromantiyo Bayu A 


\begin{tabular}{|l|l|}
\hline $\mathrm{X}>87 \%$ & Excelent \\
\hline \multicolumn{2}{|c|}{ source: $\mathrm{www}$.leadershipsfactor.com } \\
\hline
\end{tabular}

\section{RESULTS AND DISCUSSION}

\subsection{Importance Performance Analysis (IPA)}

Based on the analysis results of the questionnaire answers in the Air Freight Forwarding Angkasa Pura Cargo Terminal Juanda Airport in Surabaya, the average level of satisfaction can be seen in Table 2.

Table 2. Average Level of Satisfaction and Importance Attributes Cargo Services

\begin{tabular}{|c|c|c|c|c|c|}
\hline code & attribute Service & $\begin{array}{c}\text { Weight } \\
\text { X }\end{array}$ & $\begin{array}{c}\text { Weight } \\
\text { Y }\end{array}$ & $\overline{\mathrm{X}}$ & $\overline{\mathrm{Y}}$ \\
\hline $\mathrm{K}$ & $\begin{array}{l}\text { 1. On Time Delivery Capability } \\
\text { 2. Making the queuing system in serving consumers } \\
\text { 3. Explanation Officers Against Whole Process Delivery and } \\
\text { provide answers to questions consumers with good } \\
\text { 4. Submission of records / documents of cargo correctly }\end{array}$ & $\begin{array}{l}416 \\
307 \\
352 \\
373\end{array}$ & $\begin{array}{l}409 \\
403 \\
317\end{array}$ & $\begin{array}{l}4.2 \\
3.1 \\
3.5\end{array}$ & $\begin{array}{l}4.1 \\
4 \\
3.2\end{array}$ \\
\hline DT & $\begin{array}{l}\text { 5. Desire officers help solve the problem of cargo } \\
\text { 6. Payment of freight charges by consumers easily and quickly } \\
\text { 7. Fast service in cargo }\end{array}$ & $\begin{array}{l}394 \\
400 \\
321\end{array}$ & $\begin{array}{l}395 \\
427 \\
334\end{array}$ & $\begin{array}{l}3.9 \\
4 \\
3.2\end{array}$ & 4.3 \\
\hline $\mathrm{J}$ & $\begin{array}{l}\text { 8. Compensation for lost property damage in full } \\
\text { 9. Got operational procedures clear and complete services } \\
\text { 10. Can choose the speed cargo shipments }\end{array}$ & $\begin{array}{l}301 \\
422 \\
454\end{array}$ & $\begin{array}{l}376 \\
391 \\
397\end{array}$ & $\begin{array}{l}3 \\
4.2 \\
4.5\end{array}$ & 3.8 \\
\hline $\mathrm{E}$ & $\begin{array}{l}\text { 11. All the officers want to give attention and service with a smile } \\
\text { and a polite word } \\
\text { 12. All officers concerned with the security of cargo and handled in } \\
\text { accordance with the procedure } \\
\text { 13. Courtesy and friendliness of the staff at the cargo terminal } \\
\text { 14. Officers consumers with good care for all stages of cargo } \\
\text { processing } \\
\text { 15. Officers understand the needs of consumers }\end{array}$ & $\begin{array}{l}326 \\
336 \\
354 \\
316 \\
344\end{array}$ & $\begin{array}{l}318 \\
330 \\
390 \\
347 \\
333\end{array}$ & $\begin{array}{l}3.5 \\
3.2 \\
3.4\end{array}$ & $\begin{array}{l}3.9 \\
3.5\end{array}$ \\
\hline $\mathrm{BF}$ & $\begin{array}{l}\text { 16. Comfort customer service area } \\
\text { 17. The service area clean } \\
\text { 18. Area neat } \\
\text { 19. Areas of adequate services } \\
\text { 20. The availability of extensive parking facilities }\end{array}$ & $\begin{array}{l}312 \\
340 \\
314 \\
313 \\
294\end{array}$ & $\begin{array}{l}372 \\
347 \\
336 \\
313 \\
365\end{array}$ & $\begin{array}{l}3.1 \\
3.4 \\
3.1 \\
3.1 \\
2.9\end{array}$ & $\begin{array}{l}3.7 \\
3.5 \\
3.4 \\
3.1 \\
3.7\end{array}$ \\
\hline
\end{tabular}

Source: Personal processing

An average of twenty attributes above was added Quadrant IPA. The results of IPA analysis of the level of service performance and the level of interest of the domestic cargo terminal services, generate incoming service attributes in quadrant I - IV. For more details can be seen in Picture 3. 


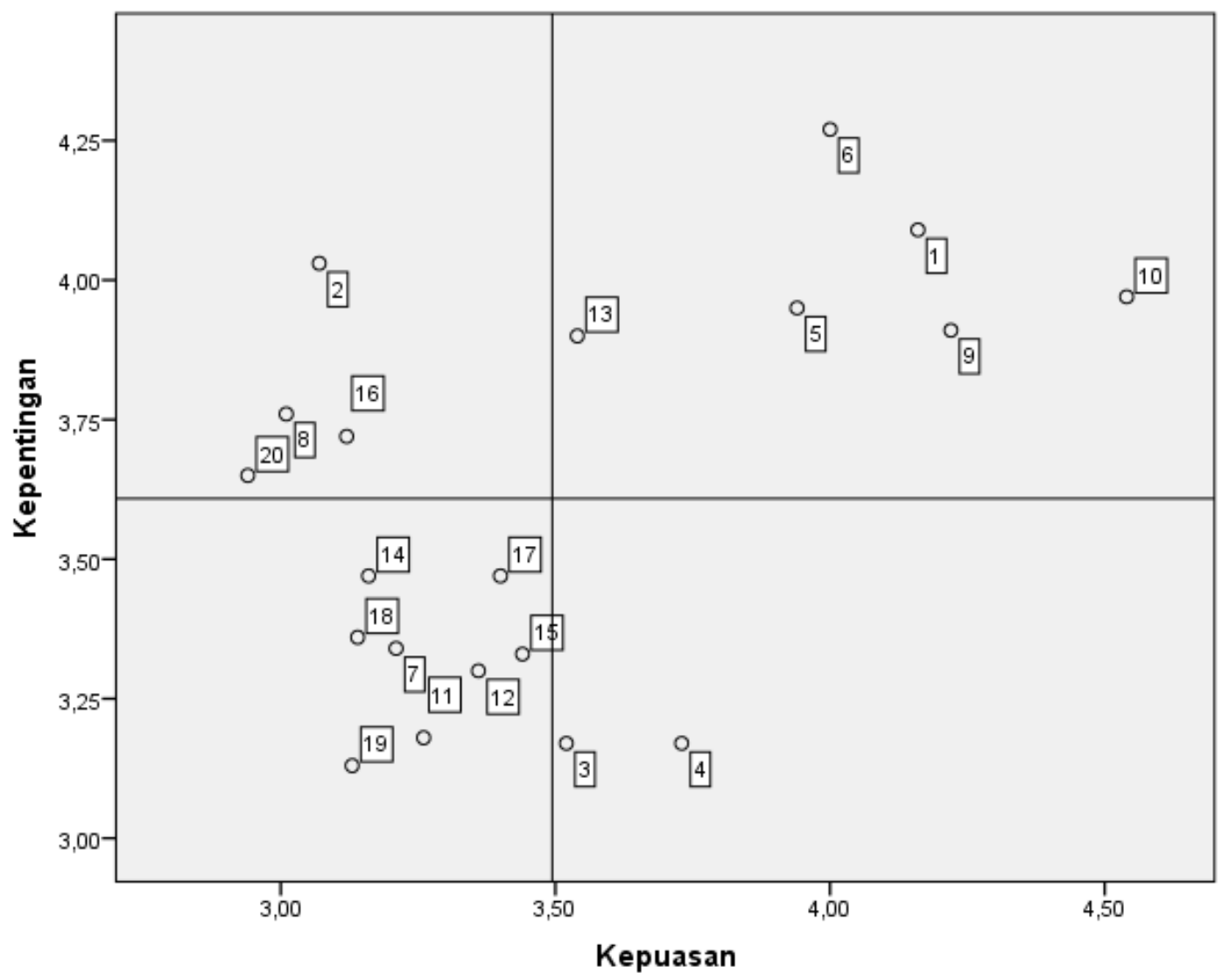

a. Quadrant 1 (Priority)

Picture 3. Quadrant IPA

Variables that entered service in this quadrant are:

- Making the queuing system in serving consumers

- Compensation for lost property damage in full

- Comfort customer service area

- The availability of extensive parking facilities

Variable service in quadrant $\mathrm{I}$, this is a major concern because it has a high value of the interest of the service but the performance of services is still low and should be improved.

b. Quadrant II (Preserve Achievement)

Service attributes that go in this quadrant are:

- Payment of freight charges by consumers easily and quickly

- On Time Delivery Capability

- Can choose the speed cargo shipments

- Courtesy and friendliness of the staff at the cargo terminal

- Desire officers help solve the problem of cargo

- Got operational procedures clear and complete services

Service attributes in quadrant II are those that have high value services and the interest of service performance was also felt was appropriate according to the respondents.

c. Quadrant III (Low Priority) 
Service attributes that go in this quadrant is

- The service area clean

- Officers consumers with good care for all stages of cargo processing

- Area neat

- Fast service in cargo meproses

- Officers understand the needs of consumers

- All the officers want to give attention and service with a smile and a polite word

- All officers concerned with the security of cargo and handled in accordance with the procedure

- Areas of adequate services

Service attributes in quadrant III has a low value service performance but also not considered important by the respondents that do not require an increase in the performance of services.

d. Quadrant IV (Tend Redundant)

Service attributes that go in this quadrant are:

- Explanation Officers Against Whole Process Delivery and provide answers to questions consumers with good

- Submission of records / documents of cargo correctly

Service attributes in quadrant IV are considered less important by respondents but has a high service performance so prone to exaggeration

\subsection{Customer Satisfaction Index (CSI)}

CSI calculations using the formulas as presented in sub-chapter analysis method. The calculation is done by first calculating the average value of the level of interest, the average level of satisfaction, value weighting factor, and weighted score. Table 3 below is the result of the measurement calculation Customer Satisfaction Index (CSI) at the Air Freight Forwarding Juanda Airport in Surabaya.

Based on the calculation results in Table 3 Air cargo expedition CSI valuePT. Angkasa Pura Cargo by $71.36 \%$. Interpetasi CSI value requires attention (Cause of concern).

Analysis of Domestic Cargo Service of Juanda Airport in Surabaya 
Table 3. Average Level of Satisfaction and Importance Attributes Cargo Services

\begin{tabular}{|c|c|c|c|c|}
\hline attribute Service & $\mathrm{X}$ & $\mathrm{Y}$ & WF & WS \\
\hline 1. On Time Delivery Capability & 4.16 & 4.09 & 5.67 & 23.58 \\
\hline 2. Making the queuing system in serving consumers & 4 & 4.03 & 5.58 & 22.34 \\
\hline $\begin{array}{l}\text { 3. Explanation Officers Against Whole Process Delivery and } \\
\text { provide answers to questions consumers with good } \\
\text { 4. Submission of records / documents of cargo correctly }\end{array}$ & 3.52 & 3.17 & 4.39 & 15.46 \\
\hline 5. Desire officers help solve the problem of cargo & 3.73 & 3.17 & 4.39 & 16.38 \\
\hline $\begin{array}{l}\text { 6. Payment of freight charges by consumers easily and quickly } \\
\text { 7. Fast service in cargo meproses }\end{array}$ & 3.94 & 3.95 & 5.47 & 21.56 \\
\hline 8. Compensation for lost property damage in full & 4 & 4.27 & 5.92 & 23.67 \\
\hline 9. Got operational procedures clear and complete services & & & & \\
\hline 10. Can choose the speed cargo shipments & 3.21 & 3.34 & 4.63 & 14.86 \\
\hline $\begin{array}{l}\text { 11. All the officers want to give attention and service with a smile and } \\
\text { a polite word }\end{array}$ & 3.01 & 3.76 & 5.21 & 15.68 \\
\hline $\begin{array}{l}\text { 12. All officers concerned with the security of cargo and handled in } \\
\text { accordance with the procedure }\end{array}$ & 4.22 & 3.91 & 5.42 & 22.86 \\
\hline 13. Courtesy and friendliness of the staff at the cargo terminal & 4.54 & 3.97 & 5.50 & 24.97 \\
\hline $\begin{array}{l}\text { 14. Officers consumers with good care for all stages of cargo } \\
\text { processing }\end{array}$ & 3.26 & 3.18 & 4.41 & 14.36 \\
\hline 15. Officers understand the needs of consumers & 3.36 & 3.3 & 4.57 & 15.36 \\
\hline 16. Comfort customer service area & & & & \\
\hline 17. The service area clean & 3.54 & 3.9 & 5,40 & 19.13 \\
\hline 18. Area neat & 3.16 & 3.47 & 4.81 & 15,19 \\
\hline 19. Areas of adequate services & & & & \\
\hline 20. The availability of extensive parking facilities & 3.44 & 3.33 & 4.61 & 15.87 \\
\hline & 3.12 & 3.72 & 5.15 & 16.08 \\
\hline & 3.4 & 3.47 & 4.81 & 16.35 \\
\hline & 3.14 & 3.36 & 4.66 & 14.62 \\
\hline & 3.13 & 3.13 & 4.34 & 13.57 \\
\hline & 2,94 & 3.65 & 5.06 & 14.87 \\
\hline total & \multirow{2}{*}{\multicolumn{3}{|c|}{72.17}} & 356,78 \\
\hline Customer Satisfaction Index & & & & $71.36 \%$ \\
\hline
\end{tabular}

Source: personal Processing

\subsection{Conclusion}

\section{CONCLUSIONS AND RECOMMENDATIONS}

1) Based on an assessment of service users, quality of service and overall customer satisfaction in the expedition Air Muaran (master) PT. Angkasa Pura cargo CSI approach, for an amount of $71.36 \%$ is obtained,that need attention (Cause of Concern).

2) Services that are essential attributes of science studies known low-performing service attributes but are considered important by the domestic cargo terminal services users and need to be increased again by the service provider is

- $\quad$ Making the queuing system in serving consumers

Analysis of Domestic Cargo Service of Juanda Airport in Surabaya

Raditya Bromantiyo Bayu A 
- Compensation for lost property damage in full

- Comfort customer service area

- The availability of extensive parking facilities

\subsection{Suggestion}

To maintain and improve the performance of the service, need to do more in-depth and continuous study of the level of service of service users in the domestic cargo terminal Juanda Airport in Surabaya. not only by using the service user as a respondent but involves also an employee service and Airport Authority office party so that all parties can make suggestions for the betterment of the domestic cargo terminal of Juanda Airport in Surabaya.

\section{REFERENCES}

Subekti Sitti, Herry Purnama Muhammad. (2015). Analisis Kualitas Pelayanan Terminal Kargo Bandar Udara Juwata Tarakan. Jurnal Perhubungan Udara Warta Ardhia. Vol 41 No. 1 Maret 2015 Hal 29-38

Ircham.(2014).Pelayanan Kargo Udara di Bandar Udara Soekarno-Hatta. Jurnal Perhubungan Udara Warta Ardhia. Vol 40 No. 2 Juni 2014, Hal 133-146

Badan Standarisasi Nasional. (2004). SNI 03-7047-2004 Terminal Kargo Bandar Udara. Jakarta: Badan Standarisasi Nasional.

Subekti Sitti. (2013). Pelayanan Kargo Udara di Terminal Kargo Domestik Bandar Udara Soekarno-Hatta). Jurnal Perhubungan Udara Warta Ardhia. Vol 39 No.2 Juni 2013 Hal 98-111

Prasetyo Agus, Sulistio Harnen, Wicaksono Achmad. (2015). Kajian Kinerja Pelayanan Terminal Kargo Domestik di Bandar Udara Juanda Surabaya. Jurnal Rekayasa Sipil Univ. Brawijaya. Vol 9 No. 3 - 2015

Abdul Majid, Suharto. (2009). CUSTOMER SERVICE DALAM BISNIS JASA TRANSPORTASI. Jakarta : PT RajaGrafindo Persada

Komputer, Wahana. (2012). Solusi Praktis \& Mudah Menguasai SPSS 20 untuk Pengolahan Data. Yogyakarta : Andi

Yarlina Lita. (2016). The Evaluation of Passenger Services Performance in Sultan Thaha Airport - Jambi. Jurnal Perhubungan Udara Warta Ardhia. Vol. 42 No. 2 juni 2016, hal 79 - 100

Yuliana Dina. (2017). The Influence of Facility, Service and Accessibility Information on Passenger Satisfaction Level at Husein Sastranegara Airport-Bandung. Jurnal Perhubungan Udara Warta Ardhia. Vol. 43 No. 1 juni 2017, Hal 27-42

Sugiyono. (2013). Statitiskan Untuk penelititan. Bandung : Alfabeta.

Noer, Lista Rusdiana. (2016) ANALISIS PENINGKATAN KUALITAS PELAYANAN MAHASISWA MAGISTER MANAJEMEN TEKNOLOGI ITS SURABAYA DENGAN METODE SERVQUAL DAN IMPORTANCE PERFORMANCE ANALYSIS (IPA). Journal of Research and Technologies. Vol. 2 No. 1 juni 2016.

Dewanti Galuh, Krisna. (2017). ANALISIS KUALITAS PELAYANAN PELANGGAN BENGKEL MOTOR "ABC" MENGGUNAKAN KONSEP SERVIS QUALITY DAN IMPORTANCE-PERFORMANCE ANALYSIS. Journal Faktor Exacta. Vol. 10 No. 2 